\title{
Association of serum chromium levels with malnutrition in hemodialysis patients
}

\author{
Ching-Wei Hsu ${ }^{1,2}$, Cheng-Hao Weng ${ }^{1,2}$, Cheng-Chia Lee ${ }^{1,2}$, Tzung-Hai Yen ${ }^{1,2}$ and Wen-Hung Huang ${ }^{1,2,3^{*}}$
}

\begin{abstract}
Background: Chromium is an essential trace metal that reduces oxidative stress and inflammation. In patients undergoing maintenance hemodialysis (MHD), a correlation among chromium exposure, inflammation, and malnutrition remains unclear. This study examined the possible effects of serum chromium levels (SCLs) in MHD patients.

Methods: Initially, $732 \mathrm{MHD}$ patients in dialysis centers were recruited. A total of 647 patients met the inclusion criteria and were stratified by SCL into four equal-sized groups: first quartile $(<0.29 \mu \mathrm{g} / \mathrm{L})$, second quartile $(0.29-$ $0.56 \mu \mathrm{g} / \mathrm{L})$, third quartile $(0.57-1.06 \mu \mathrm{g} / \mathrm{L})$, and fourth quartile $(>1.06 \mu \mathrm{g} / \mathrm{L})$. Demographic, biochemical, and dialysisrelated data were obtained for analyses. The analysis included nutritional and inflammatory markers.

Results: As compared with the highest quartile group, more subjects in the lowest quartile group were of an older age; had lower hemoglobin and creatinine levels; had a higher prevalence of DM and malnutrition (serum albumin level $<3.6 \mathrm{~g} / \mathrm{dL}$ ); and higher serum transferrin saturation and ferritin levels. A stepwise multiple linear regression analysis revealed a significant negative correlation between malnutrition and SCL ( $\beta$ coefficient $=-0.129, p=0.012$ ) and negative associations among body mass index ( $\beta$ coefficient $=-0.010, p=0.041$ ), ferritin ( $\beta$ coefficient $=-0.107, p=0.001$ ) and $\mathrm{SCL}$. A multivariate logistic regression analysis also demonstrated a negative correlation between malnutrition and SCL. With a 10-fold increase in SCL, the risk ratio of malnutrition was 0.49 (95\% confidence interval: 0.25-0.96; $p=0.039$ ).
\end{abstract}

Conclusions: SCL is significantly associated with malnutrition in MHD patients. Further evaluation of the relationship between clinical outcomes (morbidity/mortality) and SCL is necessitated.

Keywords: Chromium, End stage renal disease, Hemodialysis, Nutrition

\section{Background}

Studies have suggested that trivalent chromium is an essential nutrient; potentiates insulin action in peripheral tissue; and is essential for lipid, protein, and fat metabolism in animals and humans $[1,2]$. The lower plasma chromium level is associated with hyperglycemia, insulin resistance, high inflammatory status and increased cardiovascular risk in humans [2]. The compounds containing hexavalent chromium are widely known to have mutagenic and carcinogenic effects when inhaled or orally ingested in large amount [3, 4]. However, not all studies have reported beneficial effects of nutritional supplement with chromium $[5,6]$.

\footnotetext{
* Correspondence: williammedia@gmail.com

'Department of Nephrology and Clinical Poison Center, Chang Gung

Memorial Hospital, Linkou Medical Center, Taoyuan, Taiwan

${ }^{2}$ Chang Gung University College of Medicine, Taoyuan, Taiwan

Full list of author information is available at the end of the article
}

Chromium has been shown to accumulate in the bones of patients with end-stage renal disease (ESRD), and increased serum chromium levels (SCLs) have been found in patients undergoing maintenance hemodialysis (MHD) [7]. However, no study mentioned the clinical advantages or disadvantages of an elevated SCL in patients undergoing MHD until now.

Although traditional risk factors for cardiovascular disease are common in ESRD patients, recent clinical studies indicated that chronic inflammation and malnutrition may cause protein-energy wasting in ESRD patients and poor short-term survival in this population $[8,9]$. Correcting inflammation, malnutrition, and even protein-energy wasting may reduce mortality for patients undergoing MHD. Therefore, identifying correctable factors associated with malnutrition, inflammation, or both is important for these patients. We therefore conducted a cross-sectional

(C) The Author(s). 2019 Open Access This article is distributed under the terms of the Creative Commons Attribution 4.0 International License (http://creativecommons.org/licenses/by/4.0/), which permits unrestricted use, distribution, and 
study to evaluate the relationship among SCLs, malnutrition, and inflammation using details from clinical examinations of MHD patients.

\section{Methods \\ Patients}

Patients were identified using the following inclusion criteria: a minimum age of 18 years and on MHD more than 6 months. Initially, we enrolled 732 patients from the dialysis units of our hospital. Patients with the following conditions were excluded: malignancies $(n=10)$, obvious infectious diseases $(n=12)$, hospitalization or undergone surgery within 3 months before the study $(n=32)$. Patients were also excluded if they had ever exposed to relatively high chromium levels, including occupational exposure $(n=28)$ and living in heavily contaminated areas $(n=3)$. Finally, this study included a total of 647 MHD patients. The majority of patients underwent $3 \mathrm{HD}$ sessions of $4 \mathrm{~h}$ per week. The patients used synthetic polysulfone dialysis membrane and bicarbonate dialysate. No dialyzer reuse is practiced. The following data were collected from dialysis charts and/or electronic medical records: demographics (age and gender), relevant comorbidities (cardiovascular diseases [CVDs], hypertension and diabetes mellitus [DM]), dialysis-related data and biochemical data.

\section{Measurement of serum chromium levels and biochemical parameters}

To ensure that the patients' samples were not contaminated with chromium during HD, we collected the samples of water and dialysate by using chromium-free plastic bottles. There are 6 dialysis units in our hospital and we collected the samples of water and dialysate in each unit randomly. Therefore, 12 samples of water and dialysate were analyzed for chromium concentration. All of the blood samples of patients were collected just before the start of the mid-week HD session. The samples were drawn in syringes and needles which were batchtested and shown not to be contaminated with heavy metals. We measured the SCLs following a previously described method [10]. Briefly, $900 \mu \mathrm{L}$ of modifier solution $\left(\mathrm{HNO}_{3}\right.$ plus Triton $\left.\mathrm{X}-100\right)$ in deionized water and $100 \mu \mathrm{L}$ of serum or $100 \mu \mathrm{L}$ of $\mathrm{HNO}_{3}$ and $900 \mu \mathrm{L}$ of dialysate were added to a $1.5-\mathrm{mL}$ Eppendorf tube and mixed. After overnight refrigeration, the vessels were warmed to room temperature and whirl-mixed for 5-10 $\mathrm{s}$, and then centrifuged for $5 \mathrm{~min}$ at $11,500 \mathrm{rpm}$. The supernatants of diluted serums and dialysate samples were transferred to graphite furnace sampler cups. The chromium concentrations were determined by atomic $a b$ sorption spectrophotometer (SpectrAA-220Z; Varian, USA), with the detection limit of $0.05 \mu \mathrm{g} / \mathrm{L}$. We detected the serum levels of high-sensitivity $\mathrm{C}$-reactive protein
(hsCRP) by immunonephelometry (Nanopia CRP; Daiichi Inc., Tokyo, Japan), with a detection limit of 0.15 $\mathrm{mg} / \mathrm{L}$. We used the automated biochemical analyzers to determine the concentrations of all other biochemical parameters. We calculated the protein catabolism rate (nPCR) using validated equations and the data were normalized to the actual body weight [11]. We also evaluated the clearance of urea in study patients and the data were expressed as Kt/V [12].

For statistical analysis, all participations were divided into 4 equal-sized groups according to the SCL quartile: first $(<0.29 \mu \mathrm{g} / \mathrm{L}, \quad n=164)$, second $(0.29-0.56 \mu \mathrm{g} / \mathrm{L}, n=159)$, third $(0.57-1.06 \mu \mathrm{g} / \mathrm{L}, n=163)$, and fourth $(>1.06 \mu \mathrm{g} / \mathrm{L}$, $n=161)$ SCL quartiles.

\section{Definition of malnutrition and inflammation}

To determine the associations between SCLs and the inflammatory or nutritional status, we evaluated the serum albumin and hsCRP levels in different subgroups. MHD patients were considered to have inflammation if they exhibited an hsCRP level of $>3 \mathrm{mg} / \mathrm{L}$, which was correlated with elevated cardiovascular risk in the general population $[13,14]$. Individuals with an albumin level of $<3.6 \mathrm{~g} / \mathrm{dL}$ were considered to be malnourished. This albumin level was close to the lower limit (i.e., $3.5 \mathrm{~g} / \mathrm{dL}$ ) in our hospital and corresponded to the tenth percentile from the Third National Health and Nutrition Examination Survey of Americans $[9,15]$.

\section{Statistical analysis}

We applied a Kolmogorov-Smirnov test to determine the distribution of variables. Continuous variables with normal distribution were presented as mean \pm standard deviation and non-normal variables were shown as median with interquartile range (IQR). Categorical variables are presented as number with percentage. We used a trend test to compare the 4 study groups and a $p$ value of $<0.05$ was considered significant. Non-normally distributed continuous variables such as SCL, intact parathyroid hormone (iPTH), ferritin, and hsCRP were logarithmically converted. We used Pearson correlation coefficient to assess the association among clinical variables. To determine the correlations between log SCL and baseline variables, we applied univariate and multivariate linear regression analyses to obtain the predictive power, which were presented as $\beta$ coefficient with standard error $(S E)$. All potential variables $(p<0.05)$ from the simple linear regression analysis were entered into forward stepwise multiple linear regression analysis. To evaluate variables related to malnutrition and inflammation, we performed univariate and multivariate logistic regression analyses to obtain the odds ratio (OR) and $95 \%$ confidence interval (CI). All potential variables $(p<$ 0.05 ) found to be significant in the univariate logistic 
regression analysis were included in the forward stepwise multivariate logistic regression analysis. Data analyses were performed using Statistical Package for Social Sciences (SPSS), Version 18.0 for Windows (SPSS Inc., Chicago, IL, USA).

\section{Results}

\section{Study population characteristics}

A total of 647 MHD patients (331 men and 316 women) with a mean HD vintage (length of time on dialysis) of $9.5 \pm 6.1$ years met the inclusion criteria and were enrolled in this study. Table 1 lists their clinical characteristics including age, gender, and body mass index, along with the biological, hematological, and biochemical data. The mean patient age was $57.9 \pm 12.2$ years, and their biochemical data were as follows: median SCL, $0.57 \mu \mathrm{g} / \mathrm{L}$ (IQR: 0.29, 1.06); mean serum albumin level, $3.98 \pm 0.33$ $\mathrm{g} / \mathrm{dL}$; and median hsCRP level, $2.59 \mathrm{mg} / \mathrm{L}$ (IQR: 1.21 , 7.04). Table 1 also lists the patient characteristics for the 4 subgroups. Compared with the second SCL quartile ( $n=159$; median SCL, $0.39 \mu \mathrm{g} / \mathrm{L}$; IQR: $0.34,0.46)$, third SCL quartile $(n=163$; median SCL, $0.80 \mu \mathrm{g} / \mathrm{L}$; IQR: 0.65 , $0.92)$, and fourth SCL quartile $(n=161$; median SCL, $1.59 \mu \mathrm{g} / \mathrm{L}$; IQR: $1.26,2.26)$ groups, the first SCL quartile group ( $n=164$; median SCL, $0.20 \mu \mathrm{g} / \mathrm{L}$; IQR: $0.14,0.24$ ) seemed to comprise patients with an older age, lower hemoglobin and creatinine levels and higher prevalence of DM and malnutrition, as well as higher serum transferrin saturation and ferritin levels (Table 1). The groups did not differ in terms of gender, smoking status, body mass index, use of a fistula as a blood access, biocompatible membrane dialyzers, hypertension history, CVD, $\mathrm{HD}$ vintage, Kt/V (Daugirdas), and nPCR. Moreover, the groups did not differ in terms of serum albumin; cholesterol; triglyceride; corrected calcium and phosphate levels; iPTH; hsCRP, the presence of viral hepatitis B antigen and viral hepatitis $\mathrm{C}$ antibody.

\section{Water and dialysate chromium levels}

The chromium levels of all the water and dialysate samples $(n=12)$ were $<0.1 \mu \mathrm{g} / \mathrm{L}$ and were far below the American Association for Advancement of Medical Instrumentation (AAMI) standards (chromium, $<14 \mu \mathrm{g} / \mathrm{L}$ ).

\section{Determinants of SCLs in MHD patients}

In simple linear regression analysis, we found that log SCL were positively associated with HD vintage, hemoglobin and serum creatinine levels, but negatively associated with age, body mass index, DM, malnutrition status, log ferritin level, and transferrin saturation $(p<0.05)$. After adjusting for potential variables, we revealed that $\log$ SCL was significantly and negatively associated body mass index ( $\beta$ coefficient \pm $\mathrm{SE}=-0.010 \pm 0.005 ; p=0.041)$, malnutrition status $(\beta$ coefficient $\pm \mathrm{SE}=-0.129 \pm 0.051 ; p=0.012)$, and $\log$ ferritin level $\quad(\beta$ coefficient $\pm \mathrm{SE}=-0.107 \pm 0.031$; $p=0.001)$ in forward stepwise multiple linear regression analysis (Table 2).

\section{Probability of malnutrition in MHD patients}

In univariate logistic regression analysis, we found that the following variables were potential predictors of malnutrition: age of > 65 years; DM; catheter use for blood access; cholesterol, triglyceride, hemoglobin, creatinine, and phosphate levels; nPCR; log SCL; and hsCRP of $>3$ $\mathrm{mg} / \mathrm{L}$. After adjusting for potential variables, we revealed that age of $>65$ years $(\mathrm{OR}=1.80 ; 95 \%$ CI: $1.02-3.19 ; p=$ $0.043)$ and hsCRP of $>3.0 \mathrm{mg} / \mathrm{L}(\mathrm{OR}=2.15 ; 95 \% \mathrm{CI}$ : $1.22-3.82 ; p=0.009)$ were independent and positive predictors of malnutrition, but cholesterol $(\mathrm{OR}=0.99$; $95 \%$ CI: $0.98-1.00 ; p=0.005)$, creatinine $(\mathrm{OR}=0.73$; 95\% CI: $0.64-0.84 ; p<0.001)$ and $\log \mathrm{SCL}(\mathrm{OR}=0.49 ; 95 \% \mathrm{CI}$ : $0.25-0.96 ; p=0.039)$ were independent and negative predictors of malnutrition in forward stepwise multivariate logistic regression analysis (Table 3 ).

\section{Probability of inflammation in MHD patients}

In univariate logistic regression analysis, we found that the following variables were potential predictors of inflammation: age of > 65 years; body mass index; DM; malnutrition status; catheter use for blood access; Kt/V (Daugirdes); nPCR; and triglyceride, hemoglobin, creatinine, log ferritin, and transferrin saturation levels, but not log SCL $(\mathrm{OR}=0.92 ; 95 \% \mathrm{CI}: 0.64-1.33 ; p=0.653)$. After adjusting for potential variables, we revealed that body mass index $(\mathrm{OR}=1.15 ; 95 \%$ CI: $1.08-1.22 ; p<0.001)$, triglyceride (OR $=1.00 ; 95 \%$ CI: $1.00-1.01 ; p=0.001)$, log ferritin $(\mathrm{OR}=1.95 ; 95 \%$ CI: $1.28-2.99 ; p=0.002)$ and malnutrition $(\mathrm{OR}=2.96$; 95\% CI: $1.61-5.43 ; p<0.001)$ were independent and positive predictors of inflammation, but hemoglobin $(\mathrm{OR}=0.80 ; 95 \% \mathrm{CI}: 0.67-0.95 ; p=0.012)$ and transferrin saturation $(\mathrm{OR}=0.96$; $95 \%$ CI: 0.94-0.97; $p=$ 0.001 ) were independent and negative predictors of inflammation in forward stepwise multivariate logistic regression analysis (Table 4). The correlation among log hsCRP, ferritin, and chromium is shown in Fig. 1.

\section{Discussion}

The analytical results of this study demonstrated an association between SCLs and malnutrition (serum albumin level $<3.6 \mathrm{~g} / \mathrm{dL}$ ) in MHD patients. Following adjustment for potential variables, SCLs were negatively correlated with malnutrition in these patients. Overall, each 10-fold increase in SCL was associated with a 0.49 fold decrease in the probability of malnutrition development in these subjects. Reviewing the published articles, this study is the first to reveal the negative correlation between SCL and malnutrition in ESRD population. 
Table 1 Baseline characteristics of studied patients by quartile of SCLs ( $n=647)$

\begin{tabular}{|c|c|c|c|c|c|c|}
\hline Characteristics & $\begin{array}{l}\text { Total patients } \\
(n=647)\end{array}$ & $\begin{array}{l}\text { 1st quartile } \\
(<0.29 \mu \mathrm{g} / \mathrm{L}) \\
(n=164)\end{array}$ & $\begin{array}{l}\text { 2nd quartile } \\
(0.29-0.56 \mu \mathrm{g} / \mathrm{L}) \\
(n=159)\end{array}$ & $\begin{array}{l}\text { 3rd quartile } \\
(0.57-1.06 \mu \mathrm{g} / \mathrm{L}) \\
(n=163)\end{array}$ & $\begin{array}{l}\text { 4th quartile } \\
(>1.06 \mu \mathrm{g} / \mathrm{L}) \\
(n=161)\end{array}$ & $p$ \\
\hline \multicolumn{7}{|l|}{ Demographics } \\
\hline Age (years) & $57.9 \pm 12.2$ & $59.9 \pm 12.1$ & $58.5 \pm 11.7$ & $57.3 \pm 11.2$ & $55.9 \pm 12.7$ & 0.002 \\
\hline Female sex & $316(48.8)$ & $81(49.3)$ & $88(55.3)$ & $78(47.9)$ & $69(42.9)$ & 0.125 \\
\hline Body mass index $\left(\mathrm{kg} / \mathrm{m}^{2}\right)$ & $22.1 \pm 3.4$ & $22.4 \pm 3.7$ & $22.4 \pm 3.2$ & $22.2 \pm 3.7$ & $21.7 \pm 3.2$ & 0.062 \\
\hline Smoking (Yes) & $76(11.7)$ & $10(6.1)$ & $4(2.5)$ & $9(5.5)$ & $13(8.1)$ & 0.320 \\
\hline \multicolumn{7}{|l|}{ Co-Morbidity } \\
\hline Diabetes mellitus (Yes) & $195(30.1)$ & $58(35.4)$ & $51(32.1)$ & $45(27.6)$ & $41(25.5)$ & 0.036 \\
\hline Hypertension (Yes) & $62(9.6)$ & $16(9.8)$ & $18(11.3)$ & $13(8.0)$ & $15(9.3)$ & 0.654 \\
\hline Previous CVD (Yes) & $50(7.7)$ & $16(9.8)$ & $8(5.0)$ & $10(6.1)$ & $16(9.9)$ & 0.780 \\
\hline \multicolumn{7}{|l|}{ Dialysis Related Data } \\
\hline Hemodialysis vintage (years) & $9.5 \pm 6.1$ & $9.2 \pm 5.8$ & $9.2 \pm 5.8$ & $9.4 \pm 6.3$ & $10.3 \pm 6.5$ & 0.119 \\
\hline Erythropoietin (U/kg/week) & $61.14 \pm 47.1$ & $65.5 \pm 50.8$ & $60.12 \pm 45.9$ & $60.9 \pm 46.1$ & $58.0 \pm 45.4$ & 0.531 \\
\hline Fistula as blood access (Yes) & $496(76)$ & $120(73.2)$ & $122(76.7)$ & $122(74.8)$ & $132(82.0)$ & 0.093 \\
\hline Biocompatible membrane dialyzers (Yes) & $556(85.9)$ & $145(88.4)$ & $141(88.1)$ & $122(74.8)$ & $148(91.9)$ & 0.398 \\
\hline Kt/N (Daugirdes) & $1.7 \pm 0.3$ & $1.74 \pm 0.30$ & $1.81 \pm 0.32$ & $1.78 \pm 0.31$ & $1.78 \pm 0.33$ & 0.510 \\
\hline nPCR (g/kg/day) & $1.21 \pm 0.37$ & $1.21 \pm 0.37$ & $1.21 \pm 0.37$ & $1.23 \pm 0.37$ & $1.20 \pm 0.41$ & 0.838 \\
\hline Residual daily urine of $>100 \mathrm{~mL}$ & $202(31.2)$ & $52(32.5)$ & $50(31.4)$ & $56(36.6)$ & $44(27.3)$ & 0.538 \\
\hline \multicolumn{7}{|l|}{ Biochemical Data } \\
\hline Hemoglobin (g/dL) & $10.32 \pm 1.22$ & $10.14 \pm 1.27$ & $10.24 \pm 1.21$ & $10.38 \pm 1.19$ & $10.53 \pm 1.20$ & 0.003 \\
\hline Albumin (g/dL) & $3.98 \pm 0.33$ & $3.94 \pm 0.32$ & $3.98 \pm 0.34$ & $4.01 \pm 0.34$ & $3.99 \pm 0.32$ & 0.087 \\
\hline Albumin of $<3.6 \mathrm{~g} / \mathrm{dL}$ & $75(11.5)$ & $26(20.6)$ & $19(11.9)$ & $17(10.4)$ & $13(8.1)$ & 0.019 \\
\hline Creatinine (mg/dL) & $10.99 \pm 2.38$ & $10.8 \pm 2.6$ & $10.8 \pm 2.2$ & $11.1 \pm 2.4$ & $11.3 \pm 2.4$ & 0.020 \\
\hline Transferrin saturation (\%) & $26.3 \pm 11.4$ & $28.0 \pm 12.6$ & $26.8 \pm 10.9$ & $26.9 \pm 12.0$ & $23.8 \pm 10.0$ & 0.003 \\
\hline Ferritin $(\mu \mathrm{g} / \mathrm{L})$ & $\begin{array}{l}260.7 \\
(79.8,467.3)\end{array}$ & $\begin{array}{l}321.7 \\
(110.8,504.6)\end{array}$ & $\begin{array}{l}336.6 \\
(99.2,480.5)\end{array}$ & $\begin{array}{l}257.0 \\
(71.2,487.1)\end{array}$ & $\begin{array}{l}144.4 \\
(53.6,383.5)\end{array}$ & 0.001 \\
\hline Corrected-calcium (mg/dL) & $9.86 \pm 0.93$ & $9.7 \pm 0.9$ & $10.0 \pm 1.0$ & $9.9 \pm 0.8$ & $9.8 \pm 1.0$ & 0.236 \\
\hline Phosphate (mg/dL) & $4.82 \pm 1.31$ & $4.6 \pm 1.3$ & $4.9 \pm 1.2$ & $4.8 \pm 1.2$ & $4.9 \pm 1.4$ & 0.137 \\
\hline Intact parathyroid hormone (pg/mL) & $\begin{array}{l}239.1 \\
(88.8,444.4)\end{array}$ & $\begin{array}{l}216.2 \\
(80.4408 .6)\end{array}$ & $\begin{array}{l}249.1 \\
(86.9,423.5)\end{array}$ & $\begin{array}{l}230.3 \\
(98.6,472.7)\end{array}$ & $\begin{array}{l}248.1 \\
(103.0,475.3)\end{array}$ & 0.229 \\
\hline HsCRP (mg/L) & $2.59(1.21,7.04)$ & $2.88(1.28,8.93)$ & $2.51(1.07,6.16)$ & $2.71(1.36,6.34)$ & $2.40(1.25,7.24)$ & 0.296 \\
\hline $\mathrm{HsCRP}$ of $>3.0 \mathrm{mg} / \mathrm{dL}$ & $296(45.7)$ & $78(47.6)$ & $69(43.3)$ & $78(47.9)$ & $71(44.1)$ & 0.732 \\
\hline \multicolumn{7}{|l|}{ Cardiovascular Risks } \\
\hline Cholesterol (mg/dL) & $171.7 \pm 37.3$ & $170.3 \pm 35.1$ & $174.1 \pm 39.3$ & $172.8 \pm 38.2$ & $170.0 \pm 36.7$ & 0.865 \\
\hline Triglyceride (mg/dL) & $142.4 \pm 97.3$ & $141.6 \pm 96.8$ & $142.0 \pm 103.7$ & $147.6 \pm 105.6$ & $138.6 \pm 82.1$ & 0.924 \\
\hline Serum chromium ( $\mu \mathrm{g} / \mathrm{L})$ & $0.57(0.29,1.06)$ & $0.20(0.14,0.24)$ & $0.39(0.34,0.46)$ & $0.80(0.65,0.92)$ & $1.59(1.26,2.26)$ & $<0.001$ \\
\hline
\end{tabular}

Notes: Data presented as mean \pm standard deviation, number (percentage), and median (interquartile range). A $p$ of $<0.05$ represented significant trends among the groups. Hypertension was defined as blood pressure $\geq 140 / 90 \mathrm{mmHg}$ based on at least two measurements or regular use of antihypertensive drugs. Diabetes mellitus was diagnosed by a physician previously or by 2 measurements of fasting glucose of $126 \mathrm{mg} / \mathrm{dL}$ or more. CVD included cerebrovascular disease, coronary arterial disease, congestive heart failure, and peripheral vascular disease

Abbreviations: $C V D$ cardiovascular disease, $h S C R P$ high sensitivity $C$-reactive protein, $n P C R$ normalized protein catabolic rate, $S C L$ serum chromium level

Chromium, one of the 9 trace elements (iron, zinc, copper, manganese, chromium, cobalt, selenium, fluorine, and iodine) has been reported to be beneficial and essential for humans $[1,2]$. The content of chromium in different foods varies widely, and is dependent on chromium introduced in the growing, transport and processing of the foods [16]. Chromium deficiency has been observed in humans under special conditions, such as with long-term total parenteral nutrition supplementation [17] and severe protein-calorie malnutrition [18]. Chromium is excreted primarily in the urine through glomerular filtration [19]. It is not a surprise that 
Table 2 Determinants of SCL in studied patients $(n=647)$

\begin{tabular}{|c|c|c|c|c|}
\hline & Simple linear regression analysis & $p$ & $\begin{array}{l}\text { Forward stepwise multiple linear } \\
\text { regression analysis }\end{array}$ & $p$ \\
\hline Variables & Coefficient \pm SE & & $\beta$ coefficient \pm SE & \\
\hline Age (years) & $-0.004 \pm 0.001$ & 0.002 & & \\
\hline Body mass index $\left(\mathrm{kg} / \mathrm{m}^{2}\right)$ & $-0.011 \pm 0.005$ & 0.024 & $-0.010 \pm 0.005$ & 0.041 \\
\hline Hemodialysis vintage (years) & $0.005 \pm 0.003$ & 0.050 & & \\
\hline Diabetes mellitus (Yes $=1$ ) & $-0.096 \pm 0.036$ & 0.008 & & \\
\hline Albumin of $<3.6 \mathrm{~g} / \mathrm{dL}($ Yes $=1)$ & $-0.131 \pm 0.051$ & 0.011 & $-0.129 \pm 0.051$ & 0.012 \\
\hline Hemoglobin (mg/dL) & $0.041 \pm 0.013$ & 0.002 & & \\
\hline Creatinine (mg/dL) & $0.014 \pm 0.007$ & 0.042 & & \\
\hline Transferrin saturation (\%) & $-0.003 \pm 0.001$ & 0.020 & & \\
\hline Log ferritin (pg/mL) & $-0.111 \pm 0.033$ & 0.001 & $-0.107 \pm 0.031$ & 0.001 \\
\hline
\end{tabular}

Abbreviations: Log logarithmic transformation, SE standard error, SCL serum chromium level

chromium levels have been shown to be elevated in the serum of ESRD population [7, 20]. Moreover, although studies indicated that exposure to chromium is a precipitating factor for development of chronic kidney disease in general population [21, 22], no report exists regarding the correlation between SCL and prognosis in MHD patients. A future study is needed to determine whether SCL can serve as a prognostic marker in this population. A similar study is currently underway in our hospital.

In patients undergoing MHD, disturbances of trace element metabolism might occur because of (1) alterations in gastrointestinal absorption, (2) affected appetite by uremia, and (3) transport during the dialysis procedure [23]. Theoretically, substances with lower concentrations in the dialysate than in the blood tend to be removed by dialysis. On the contrary, substances with higher concentrations in the dialysate than in the blood tend to increase in the blood. However, in most patients, dialysis is an unlikely cause of trace element deficiencies, possibly because the trace elements in the blood have formed a complex with cellular components and proteins [24]. However, chronic toxicity may be a potential hazard if the water supply or dialysis equipment is contaminated. In this study, the chromium levels of all the water and dialysate samples $(n=12)$ were $<0.1 \mu \mathrm{g} / \mathrm{L}$ (far below the AAMI standards [chromium, $<14 \mu \mathrm{g} / \mathrm{L}$ ]). After excluding the abovementioned possibilities secondary to dialysis, diet has the largest effect on the SCL of MHD patients.

Trivalent chromium is an essential nutrient that plays a role in the metabolism of certain sugars, proteins, and fats by potentiating the action of insulin [2, 19]. However, occupational or environmental exposure to

Table 3 Probability of malnutrition (serum albumin level $<3.6 \mathrm{~g} / \mathrm{dL})$ in studied patients $(n=647)$

\begin{tabular}{|c|c|c|c|c|}
\hline & Univariate logistic regression analysis & $p$ & $\begin{array}{l}\text { Forward stepwise multivariate } \\
\text { logistic regression analysis }\end{array}$ & $p$ \\
\hline Variables & $\begin{array}{l}\text { Odds ratio } \\
\text { ( } 95 \% \text { confidence interval) }\end{array}$ & & $\begin{array}{l}\text { Odds ratio } \\
\text { ( } 95 \% \text { confidence interval) }\end{array}$ & \\
\hline Age > 65 years (Yes vs. No) & $3.40(2.09-5.55)$ & $<0.001$ & $1.80(1.02-3.19)$ & 0.043 \\
\hline Diabetes mellitus (Yes vs. No) & $1.71(1.04-2.79)$ & 0.033 & & \\
\hline Using catheter as blood access (Yes vs. No) & $3.66(1.35-10.0)$ & 0.011 & & \\
\hline Cholesterol (mg/dL) (each increase, $1 \mathrm{mg} / \mathrm{dL}$ ) & $0.98(0.98-0.99)$ & $<0.001$ & $0.99(0.98-1.00)$ & 0.005 \\
\hline Triglyceride (mg/dL) (each increase, $1 \mathrm{mg} / \mathrm{dL}$ ) & $1.00(0.99-1.00)$ & 0.032 & & \\
\hline Hemoglobin (g/dL) & $0.55(0.45-0.69)$ & $<0.001$ & & \\
\hline Creatinine $(\mathrm{mg} / \mathrm{dL}$ ) (each increase, $1 \mathrm{mg} / \mathrm{dL}$ ) & $0.65(0.58-0.74)$ & $<0.001$ & $0.73(0.64-0.84)$ & $<0.001$ \\
\hline Phosphate (mg/dL) (each increase, $1 \mathrm{mg} / \mathrm{dL}$ ) & $0.67(0.55-0.82)$ & $<0.001$ & & \\
\hline nPCR (g/kg/day) & $0.45(0.22-0.93)$ & 0.030 & & \\
\hline Log SCL ( $\mu \mathrm{g} / \mathrm{L})$ (each increase, $10 \mu \mathrm{g} / \mathrm{L})$ & $0.46(0.25-0.83)$ & $<0.001$ & $0.49(0.25-0.96)$ & 0.039 \\
\hline hsCRP of > 3.0 mg/L (Yes vs. No) & $2.90(1.74-4.84)$ & $<0.001$ & $2.15(1.22-3.82)$ & 0.009 \\
\hline
\end{tabular}

Abbreviations: Log logarithmic transformation, $h S C R P$ high sensitivity C-reactive protein, $n P C R$ normalized protein catabolic rate, SCL serum chromium level 
Table 4 Probability of inflammation (hsCRP $>3.0 \mathrm{mg} / \mathrm{L}$ ) in studied patients $(n=647)$

\begin{tabular}{|c|c|c|c|c|}
\hline & Univariate logistic regression analysis & $p$ & $\begin{array}{l}\text { Forward stepwise multivariate } \\
\text { logistic regression analysis }\end{array}$ & $p$ \\
\hline Variables & $\begin{array}{l}\text { Odds ratio } \\
\text { ( } 95 \% \text { confidence interval) }\end{array}$ & & $\begin{array}{l}\text { Odds ratio } \\
\text { (95\% confidence interval) }\end{array}$ & \\
\hline Age > 65 years (Yes vs. No) & $1.68(1.18-2.39)$ & 0.004 & & \\
\hline Body mass index $\left(\mathrm{kg} / \mathrm{m}^{2}\right)$ (each increase, $1 \mathrm{~kg} / \mathrm{m}^{2}$ ) & $1.14(1.08-1.20)$ & $<0.001$ & $1.15(1.08-1.22)$ & $<0.001$ \\
\hline Diabetes mellitus (Yes vs. No) & $1.96(1.39-2.75)$ & $<0.001$ & & \\
\hline Using catheter as blood access (Yes vs. No) & $2.67(1.00-7.14)$ & 0.011 & & \\
\hline Kt/N (Daugirdes) (each increase, 1) & $0.35(0.21-0.59)$ & $<0.001$ & & \\
\hline nPCR (each increase, 1 g/kg/day) & $0.57(0.37-0.87)$ & 0.010 & & \\
\hline Triglyceride (mg/dL) (each increase, 1 mg/dL) & $1.00(1.00-1.01)$ & $<0.001$ & $1.00(1.00-1.01)$ & 0.001 \\
\hline Hemoglobin (g/dL) & $0.81(0.71-0.93)$ & 0.002 & $0.80(0.67-0.95)$ & 0.012 \\
\hline Creatinine (mg/dL) (each increase, 1 mg/dL) & $0.93(0.87-0.99)$ & 0.022 & & \\
\hline Transferrin saturation (\%) (each increase, 1\%) & $0.97(0.95-0.98)$ & $<0.001$ & $0.96(0.94-0.97)$ & 0.001 \\
\hline Log Ferritin (each increase, 10) & $1.62(1.18-2.22)$ & 0.003 & $1.95(1.28-2.99)$ & 0.002 \\
\hline Albumin of $<3.6 \mathrm{~g} / \mathrm{dL}$ (Yes vs. No) & $2.91(1.74-4.83)$ & $<0.001$ & $2.96(1.61-5.43)$ & $<0.001$ \\
\hline
\end{tabular}

Abbreviations: $\log$ logarithmic transformation, $h s C R P$ high sensitivity C-reactive protein, $n P C R$ normalized protein catabolic rate

hexavalent chromium-containing compounds may cause multi-organ toxicity such as renal damage, asthma, and some cancers $[3,25]$. It is worth noting that ingested hexavalent chromium is reduced efficiently to the trivalent form in the gastrointestinal tract [26]. Absorption of trivalent chromium can be facilitated by the type of chromium ingested, as well as the effect of vitamins, proteins, drugs, and other nutritional factors, in combination with starch, ascorbic acid, minerals, oxalate, and amino acids [27-29]. Picolinic and nicotinic acids have also been demonstrated to facilitate the absorption of trivalent chromium through the intestinal wall [30]. It is interesting that Anderson et al. indicated that foods high in potassium, saturated fat, and sodium also tend to be high in chromium [31]. Ingestion of phosphorous, vitamin B6, proteins, and carbohydrates also correlated with the ingestion of chromium. In addition, some amino acids such as histidine and glutamic acid increased the absorption of chromium from the intestine [32]. To our knowledge, dietary restriction of potassium, phosphorous, protein, sodium, and fat is recommended for patients with chronic kidney disease with or without dialysis. However, calculations regarding the ingested amount of chromium in restricted diets of patients with dialysis are lacking. In the general population, the recommended dose of trivalent chromium is $50-200 \mu \mathrm{g}$ per day [33]. However, without additional chromium supplementation, more than $90 \%$ of patients' daily diets were below this recommended level $(<50 \mu \mathrm{g} /$ day $)$ [34]. Dietary chromium was also correlated with dietary calories $(15 \mu \mathrm{g}$ chromium $/ 1000 \mathrm{kcal}$ in the typical diet consumed in the United States [31]. From the previously
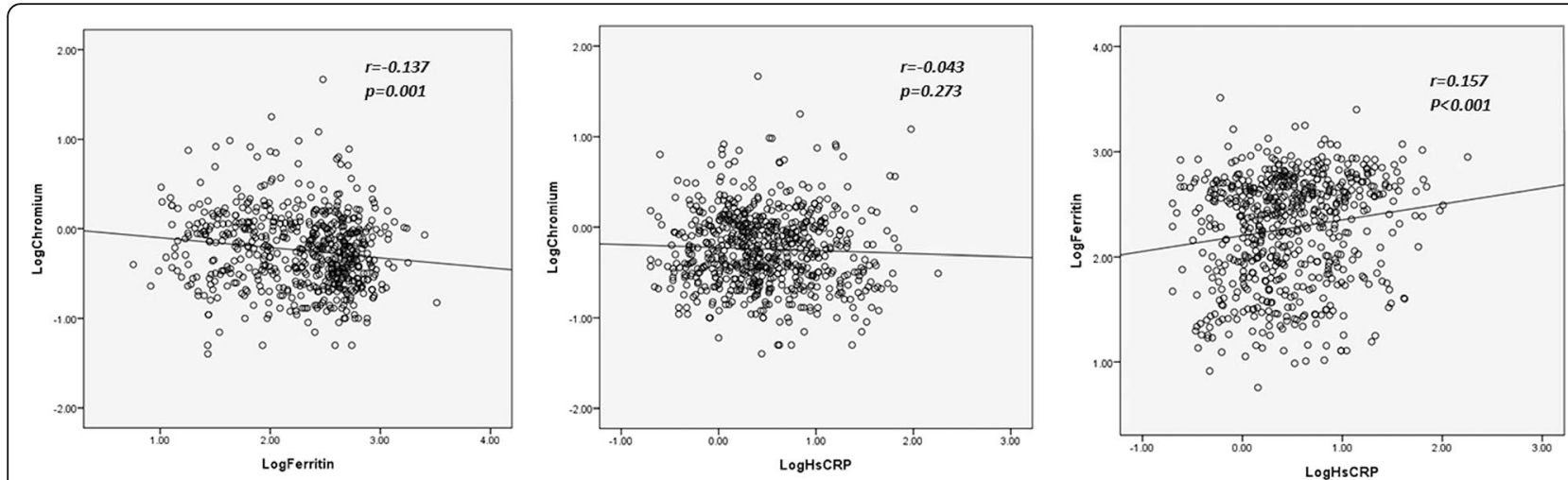

Fig. 1 Relationship between logarithmic transformation of hsCRP, ferritin, and chromium. The custom equations were as follows: Log hsCRP $=-$ 0.056 [Log chromium] + 0.463, ( $p=0.273)$; Log ferritin = - 0.168 [Log chromium] + 2.23, $(p=0.001)$; Log hsCRP = 0.164 [Log ferritin] $+0.096,(p<0.001)$. Abbreviations: hsCRP, high-sensitivity C-reactive protein; Log, Logarithmic transformation 
mentioned studies and our findings, we can conclude that there is a positive correlation between nutrition and dietary chromium.

Until now, the normal range and clinical role of serum chromium levels are still worthy of discussion, especially for MHD patients. In normal subjects, serum chromium levels range from $0.038 \mu \mathrm{g} / \mathrm{L}$ to $150 \mu \mathrm{g} / \mathrm{L}$ [35]. Volpe et al. found that the mean serum chromium levels were from $0.26 \mu \mathrm{g} / \mathrm{L}$ to $2.62 \mu \mathrm{g} / \mathrm{L}$ after supplementation with $400 \mu \mathrm{g} /$ day of chromium in the form of chromium picolinate for 12 weeks [36]. In the current study, the SCL ranged from $0.04 \mu \mathrm{g} / \mathrm{L}$ to $46.3 \mu \mathrm{g} / \mathrm{L}$, which was within the safe range as previously mentioned. The discrepancy of SCL in these MHD patients may be attributed to the following causes: (1) $31.2 \%$ patients had residual daily urine of $>100 \mathrm{~mL} /$ day, which would decrease the SCL by urinary excretion of chromium in these patients, (2) diet is one of the main sources of chromium exposure, but there are large individual variations due to different amounts of dietary intake and habits, (3) although all studied patients had been prescribed vitamin B complex (contained nicotinamide, $15 \mathrm{mg} /$ tablet, and vitamin B6, $1 \mathrm{mg} /$ tablet) which could increase the absorption of dietary chromium, some of them had poor drug compliance. A further research is needed to determine the exact causes of the discrepancy of SCL in dialysis patients.

Chronic, low-grade inflammation has been considered a hallmark feature in patients with chronic kidney disease [37], and being contributing to the development of protein-energy wasting, as well as accountable for cardiovascular and all-cause mortality [37]. The elevation of inflammatory markers such as C-reactive protein is often observed in chronic dialysis patients [38]. In an animal study [39], chromium supplement could ameliorate inflammation in the respiratory system of type 2 diabetes rats. In human studies, Saiyed et al. [40] revealed that chromium dinicocysteinate supplementation has beneficial effects on reducing vascular inflammation and oxidative stress compared to placebo; Jamilian et al. [41] found that hs-CRP level is decreased after taking chromium for 8 weeks in women with polycystic ovary syndrome. However, we did not found the association between SCL and inflammation in MHD patients, which may be due to the complicated and different mechanisms of inflammation in dialysis patients as compared with the general population [42]. Nevertheless, we found that in the 4 SCL quartile groups, the serum ferritin level decreased as SCL increased (Table 1), and ferritin levels were negatively associated with SCLs (Table 2 and Fig. 1). A study in rats by Ani et al. [43] showed that the serum concentration of ferritin was reduced by $22 \%$ following intraperitoneal injections with chromium $(1 \mathrm{mg} / \mathrm{kg})$ for 45 days compared with rats injected with saline alone. A study in men by Lukaski et al. [44] indicated that high-dose and long-term chromium picolinate supplement may predispose an individual to iron deficiency. These reports have suggested that chromium may compete with iron for binding to apo-transferrin, and further influence the related biochemical parameters because of the chemical similarities between the two metal ions [43, 45, 46]. On the basis of this interaction, we may observe the negative association between SCL and ferritin in this clinical study. In addition, after adjustment with ferritin and hemoglobin levels, we did not found a significant trend between the doses of erythropoietin and SCL $(p=0.588)$ in the four subgroups. There was also no statistically significant relationship between SCL and the doses of erythropoietin $(p=0.680)$ in these studied patients. Hence, low chromium level may not be a reason for erythropoietin resistance in dialysis population. However, a further study is needed to determine the relationship and to explore the mechanism.

This study has some limitations. First, it was a crosssectional study with patients recruited from a single institution; therefore, the results may not be applicable to ESRD patients from other hospitals. Additional largescale, multi-center studies are required to confirm our observations. Second, no acceptable indicators have been identified for determining chromium status because chromium concentrations in biological tissues and fluids do not reflect metabolically active chromium pools in the body [47]. Although evaluation of the chromium content in the bones of ESRD patients is another method for assessing chromium levels [48], this invasive procedure may involve some risks. Third, the mean corpuscular volume levels of red blood cells were not available in this study, the influence of chromium on iron metabolism and erythropoiesis could not be clearly assessed. Finally, we did not verify the valence of the serum chromium. However, studies have indicated that patients' serum chromium can be considered to be trivalent $[29,49]$.

\section{Conclusions}

This study is the first to demonstrate that SCLs are negatively associated with malnutrition in MHD patients. Additional studies are required to clarify the role of SCLs in inflammation and related comorbidities in this population.

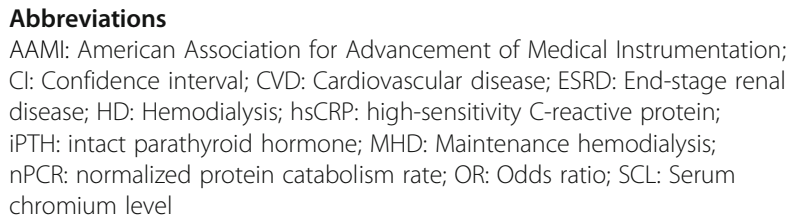

AAMI: American Association for Advancement of Medical Instrumentation; Cl: Confidence interval; CVD: Cardiovascular disease; ESRD: End-stage renal disease; HD: Hemodialysis; hsCRP: high-sensitivity C-reactive protein; iPTH: intact parathyroid hormone; MHD: Maintenance hemodialysis; nPCR: normalized protein catabolism rate; OR: Odds ratio; SCL: Serum chromium level

\section{Acknowledgements}

We thank the members of the Statistic Center in Chang Gung Memorial Hospital for their invaluable and dedicated assistance. 


\section{Authors' contributions}

CWH formed the study concept, interpreted the results, and drafted the manuscript. CHW and CCL collected and analyzed the data. THY analyzed the data and revised the manuscript. WHH provided the statistical expertise and comments on the manuscript drafts. All authors read and approved the final manuscript.

\section{Funding}

Ching-Wei Hsu received funding through a research grant from Chang Gung Memorial Hospital, Linkou (CMRPG3F2152). The funding body had no role in the design of the study and collection, analysis, and interpretation of data and in writing the manuscript

\section{Availability of data and materials}

The datasets used and/or analyzed during the current study are available from the corresponding author on reasonable request.

\section{Ethics approval and consent to participate}

This study complied with the Declaration of Helsinki guidelines and was approved by the medical ethics committee of Chang Gung Memorial Hospital, an academic medical center in North Taiwan. The written informed consent was obtained from participants. All the data were analysed anonymously. All medical records during the study period, including medical history, laboratory data, and inclusion and exclusion factors were reviewed by nephrologists. In addition, all individual information was securely protected and was only available to the investigators.

\section{Consent for publication}

Not applicable.

\section{Competing interests}

The authors declare that they have no competing interests.

\section{Author details}

'Department of Nephrology and Clinical Poison Center, Chang Gung Memorial Hospital, Linkou Medical Center, Taoyuan, Taiwan. ${ }^{2}$ Chang Gung University College of Medicine, Taoyuan, Taiwan. ${ }^{3}$ Department of Nephrology and Clinical Poison Center, Chang Gung Memorial Hospital, 199, Tung-Hwa North Road, Taipei, Taiwan, Republic of China.

\section{Received: 5 April 2019 Accepted: 19 July 2019}

\section{Published online: 05 August 2019}

\section{References}

1. Lipko M, Debski B. Mechanism of insulin-like effect of chromium (III) ions on glucose uptake in $\mathrm{C} 2 \mathrm{C} 12$ mouse myotubes involves ROS formation. J Trace Elem Med Biol. 2018:45:171-5.

2. Ngala RA, Awe MA, Nsiah P. The effects of plasma chromium on lipid profile, glucose metabolism and cardiovascular risk in type 2 diabetes mellitus. A case - control study. PLoS One. 2018;13(7):e0197977.

3. Mamyrbaev AA, Dzharkenov TA, Imangazina ZA, Satybaldieva UA. Mutagenic and carcinogenic actions of chromium and its compounds. Environ Health Prev Med. 2015;20(3):159-67.

4. Vincent JB, Lukaski HC. Chromium. Adv Nutr. 2018;9(4):505-6.

5. Lukaski HC, Siders WA, Penland JG. Chromium picolinate supplementation in women: effects on body weight, composition, and iron status. Nutrition 2007;23(3):187-95.

6. Vincent JB. New evidence against chromium as an essential trace element. J Nutr. 2017:147(12):2212-9.

7. Prodanchuk M, Makarov O, Pisarev E, Sheiman B, Kulyzkiy M. Disturbances of trace element metabolism in ESRD patients receiving hemodialysis and hemodiafiltration. Cent European J Urol. 2014;66(4):472-6.

8. Ikizler TA, Cano NJ, Franch H, Fouque D, Himmelfarb J, Kalantar-Zadeh K, et al. Prevention and treatment of protein energy wasting in chronic kidney disease patients: a consensus statement by the International Society of Renal Nutrition and Metabolism. Kidney Int. 2013:84(6):1096-107.

9. Lin JL, Lin-Tan DT, Yen TH, Hsu CW, Jenq CC, Chen KH, et al. Blood lead levels, malnutrition, inflammation, and mortality in patients with diabetes treated by long-term hemodialysis. Am J Kidney Dis. 2008;51(1):107-15.

10. Savarino L, Greco M, Cenni E, Cavasinni L. Rotini R, Baldini N, et al. Differences in ion release after ceramic-on-ceramic and metal-on-metal total hip replacement. Medium-term follow-up. J Bone Joint Surg Br. 2006;88(4): 472-6.

11. Sargent JA. Control of dialysis by a single-pool urea model: the National Cooperative Dialysis Study. Kidney Int Suppl. 1983:13:S19-25.

12. Daugirdas JT. The post: pre-dialysis plasma urea nitrogen ratio to estimate $k$. tN and NPCR: mathematical modeling. Int J Artif Organs. 1989:12(7):411-9.

13. Pupim LB, Caglar K, Hakim RM, Shyr Y, Ikizler TA. Uremic malnutrition is a predictor of death independent of inflammatory status. Kidney Int. 2004; 66(5):2054-60.

14. Wanner C, Metzger T. C-reactive protein a marker for all-cause and cardiovascular mortality in haemodialysis patients. Nephrol Dial Transplant. 2002;17(Suppl 8):29-32.

15. Kalantar-Zadeh K. Recent advances in understanding the malnutritioninflammation-cachexia syndrome in chronic kidney disease patients: what is next? Semin Dial. 2005:18(5):365-9.

16. Anderson RA, Bryden NA, Polansky MM. Dietary chromium intake. Freely chosen diets, institutional diet, and individual foods. Biol Trace Elem Res. 1992;32:117-21.

17. Zemrani B, McCallum Z, Bines JE. Trace Element Provision in Parenteral Nutrition in Children: One Size Does Not Fit All. Nutrients. 2018;10(11).

18. de Onis M, Zeithuber J, Martinez-Costa C. Nutritional disorders in the proposed 11th revision of the international classification of diseases: feedback from a survey of stakeholders. Public Health Nutr. 2016;19(17): $3135-41$

19. Dioni L, Sucato S, Motta V, lodice S, Angelici L, Favero C, et al. Urinary chromium is associated with changes in leukocyte miRNA expression in obese subjects. Eur J Clin Nutr. 2017;71(1):142-8.

20. Tonelli M, Wiebe N, Hemmelgarn B, Klarenbach S, Field C, Manns B, et al. Trace elements in hemodialysis patients: a systematic review and metaanalysis. BMC Med. 2009;7:25.

21. Tsai TL, Kuo CC, Pan WH, Chung YT, Chen CY, Wu TN, et al. The decline in kidney function with chromium exposure is exacerbated with co-exposure to lead and cadmium. Kidney Int. 2017;92(3):710-20.

22. Wedeen RP, Qian LF. Chromium-induced kidney disease. Environ Health Perspect. 1991;92:71-4.

23. Smythe WR, Alfrey AC, Craswell PW, Crouch CA, Ibels LS, Kubo H, et al. Trace element abnormalities in chronic uremia. Ann Intern Med. 1982;96(3):302-10.

24. Filler G, Felder S. Trace elements in dialysis. Pediatr Nephrol. 2014;29(8):1329-35.

25. Norseth T. The carcinogenicity of chromium. Environ Health Perspect. 1981; 40:121-30.

26. Ray RR. Adverse hematological effects of hexavalent chromium: an overview. Interdiscip Toxicol. 2016;9(2):55-65.

27. Bryson WG, Goodall CM. Differential toxicity and clearance kinetics of chromium (III) or (VI) in mice. Carcinogenesis. 1983;4(12):1535-9.

28. Dowling HJ, Offenbacher EG, Pi-Sunyer FX. Absorption of inorganic, trivalent chromium from the vascularly perfused rat small intestine. J Nutr. 1989; 119(8):1138-45

29. Lamson DW, Plaza SM. The safety and efficacy of high-dose chromium. Altern Med Rev. 2002;7(3):218-35.

30. Anderson RA, Bryden NA, Polansky MM. Lack of toxicity of chromium chloride and chromium picolinate in rats. J Am Coll Nutr. 1997;16(3):273-9.

31. Anderson RA, Kozlovsky AS. Chromium intake, absorption and excretion of subjects consuming self-selected diets. Am J Clin Nutr. 1985;41(6):1177-83.

32. Anderson RA, Polansky MM, Bryden NA. Stability and absorption of chromium and absorption of chromium histidinate complexes by humans. Biol Trace Elem Res. 2004;101(3):211-8.

33. Mclver DJ, Grizales AM, Brownstein JS, Goldfine AB. Risk of type 2 diabetes is lower in US adults taking chromium-containing supplements. J Nutr. 2015;145(12):2675-82.

34. Mertz W. Some aspects of nutritional trace element research. Fed Proc. 1970;29(4):1482-8

35. Versieck J, De Rudder J, Barbier F. Serum chromium levels. JAMA. 1979; 242(15):1613.

36. Volpe SL, Huang HW, Larpadisorn K, Lesser II. Effect of chromium supplementation and exercise on body composition, resting metabolic rate and selected biochemical parameters in moderately obese women following an exercise program. J Am Coll Nutr. 2001;20(4):293-306.

37. Akchurin OM, Kaskel F. Update on inflammation in chronic kidney disease. Blood Purif. 2015;39(1-3):84-92.

38. Nowak KL, Chonchol M. Does inflammation affect outcomes in dialysis patients? Semin Dial. 2018;31(4):388-97. 
39. Kolahian S, Sadri H, Shahbazfar AA, Amani M, Mazadeh A, Mirani M. The effects of leucine, zinc, and chromium supplements on inflammatory events of the respiratory system in type 2 diabetic rats. PLoS One. 2015;10(7): e0133374.

40. Saiyed ZM, Lugo JP. Impact of chromium dinicocysteinate supplementation on inflammation, oxidative stress, and insulin resistance in type 2 diabetic subjects: an exploratory analysis of a randomized, double-blind, placebocontrolled study. Food Nutr Res. 2016;60:31762.

41. Jamilian M, Bahmani F, Siavashani MA, Mazloomi M, Asemi Z, Esmaillzadeh A. The effects of chromium supplementation on endocrine profiles, biomarkers of inflammation, and oxidative stress in women with polycystic ovary syndrome: a randomized, double-blind. Placebo-Controlled Trial Biol Trace Elem Res. 2016;172(1):72-8.

42. Mihai S, Codrici E, Popescu ID, Enciu AM, Albulescu L, Necula LG, et al. Inflammation-related mechanisms in chronic kidney disease prediction, progression, and outcome. J Immunol Res. 2018;2018:2180373.

43. Ani M, Moshtaghie AA. The effect of chromium on parameters related to iron metabolism. Biol Trace Elem Res. 1992;32:57-64.

44. Lukaski HC, Bolonchuk WW, Siders WA, Milne DB. Chromium supplementation and resistance training: effects on body composition, strength, and trace element status of men. Am J Clin Nutr. 1996;63(6):954-65.

45. Angelova MG, Petkova-Marinova TV, Pogorielov MV, Loboda AN, NedkovaKolarova VN, Bozhinova AN. Trace element status (Iron, zinc, copper, chromium, cobalt, and nickel) in Iron-deficiency Anaemia of children under 3 years. Anemia. 2014;2014:718089.

46. Bjørklund G, Aaseth J, Skalny AV, Suliburska J, Skalnaya MG, Nikonorov AA, et al. Interactions of iron with manganese, zinc, chromium, and selenium as related to prophylaxis and treatment of iron deficiency. J Trace Elem Med Biol. 2017:41:41-53.

47. Lukaski HC. Chromium as a supplement. Annu Rev Nutr. 1999;19:279-302.

48. D'Haese PC, Couttenye MM, Lamberts LV, Elseviers MM, Goodman WG, Schrooten I, et al. Aluminum, iron, lead, cadmium, copper, zinc, chromium, magnesium, strontium, and calcium content in bone of end-stage renal failure patients. Clin Chem. 1999;45(9):1548-56.

49. Baselt R. Chromium in Disposition of Toxic Drugs and Chemicals in Man Chemical Toxicology Institute, Foster City, CA, Placed Published: 2008.

\section{Publisher's Note}

Springer Nature remains neutral with regard to jurisdictional claims in published maps and institutional affiliations.

Ready to submit your research? Choose BMC and benefit from:

- fast, convenient online submission

- thorough peer review by experienced researchers in your field

- rapid publication on acceptance

- support for research data, including large and complex data types

- gold Open Access which fosters wider collaboration and increased citations

- maximum visibility for your research: over $100 \mathrm{M}$ website views per year

At $\mathrm{BMC}$, research is always in progress.

Learn more biomedcentral.com/submissions 